\section{Discussion}

Our success rate has been at least as good as the average reported with the use of other diverse techniques. However, this would not be sufficient recommendation for widespread adoption of the method, were it not for the additional important advantage of greatly increased comfort, particularly for acutely ill patients. The use of a sandbag, which is necessary with the patient prone, has been avoided, with its accompaniments of discomfort, nausea in susceptible patients, and occasional syncope from obstruction of the venous return.

Patients cooperate well, and the tendency to transfix the kidney with the production of a painful anterior haematoma is minimized. Haemorrhage sufficient to require blood transfusion was not encountered, and surgical intervention has never been called for. The operator's comfort is ensured, since he too is sitting.

Possible disadvantages of the method stem from the fact that the kidney is not held against the diaphragm. Respiration therefore produces little swing in the exploring needle, so that the operator may be less confident of the depth of the kidney. Further, a sclerotic kidney may escape anteriorly at the moment of biopsy. However, these difficulties are in some degree common to all percutaneous techniques.

\section{Summary}

The technique of renal biopsy in the sitting position is described. In a consecutive series of 164 biopsies taken in the sitting position, $138(84 \%)$ satisfactory specimens were obtained.

Grateful acknowledgement is made to Dr. M. McConnell, Consultant Pathologist, and Mr. Alan Scott, Senior Technician, Department of Histology, for the consistently high standard of the histological preparations. We would also like to thank the nursing staff of the Artificial Kidney Unit for skilful assistance.

\section{REFERENCES}

Iversen, P., and Brun, C. (1951). Amer. F. Med., 11, 324. Kark, R. M., and Muehrcke, R. C. (1954). Lancet, 1, 1047. Kellow, W. F., Cotsonas, N. J., Chomet, B., and Zimmerman, H. J. (1959). Arch. intern. Med., 104, 353.

Kerr, D. N. S. (1960). Lancet, 2, 1370 .

Phillipi, P. J., Robinson, R. R., and Langelier, P. R. (1961). Arch. intern. Med., 108, 739 .

\title{
Occupational Infections in the Edinburgh Abattoir
}

\author{
M. E. SCHONELL,* M.B., B.S., M.R.C.P.ED. ; J. G. BROTHERSTON, † F.R.C.V.S., DIP.BACT. \\ R. C. S. BURNETT, $\ddagger$ M.B., CH.B., D.P.H.; J. CAMPBELL, † A.I.M.L.T. ; JOYCE D. COGHLAN,§ B.SC., PH.D. \\ MARGARET A. J. MOFFAT, $\|$ B.SC., PH.D. ; J. NORVAL, M.R.C.V.S. ; J. A. W. SUTHERLAND,** F.I.M.L.T.
}

Brit. med. F., 1966, 2, 148-150

By reason of his occupation the abattoir worker is at particular risk of acquiring one or more of the prevalent zoonoses. In Great Britain these include Q fever, brucellosis, leptospirosis, and louping-ill.

$Q$ fever was first recognized by Derrick (1937) after an outbreak of febrile illness among Brisbane abattoir workers. Since then several outbreaks of $\mathrm{Q}$ fever among abattoir workers have been reported (Irons and Hooper, 1947 ; Shepard, 1947 ; Beech et al., 1962 ; Tonge and Kennedy, 1963). In Great Britain brucellosis is primarily a disease of cattle, and so far only Brucella abortus has been incriminated. Farmers, dairy workers, and veterinary surgeons who come into contact with infected animals or persons who drink unpasteurized milk may become infected (Bothwell, 1963). Brucellosis has also been reported in butchers and slaughtermen (Dalrymple-Champneys, 1960). Leptospirosis is a disease known to occur among several different occupational groups where unhygienic working conditions allow rats and other rodents to proliferate. Cases have been reported in persons employed in the meat trade (Alston and Broom, 1958; Forbes and Wannan, 1964). Louping-ill, a tick-borne meningo-encephalitis, causes serious economic loss of sheep in South-west Scotland, and serological evidence of infection in Glasgow abattoir workers has been reported by Lawson et al. (1949).

* Lecturer, Department of Respiratory Diseases and Tuberculosis, University of Edinburgh.

t Moredun Institute, Edinburgh.

Assistant Medical Officer of Health, City of Edinburgh.

S Lecturer, Department of Bacteriology, University of Edinburgh.

Vecturer, Department of Bacterio, Gity Hospital, Edinburgh.

Chief Veterinary Inspector to the City of Edinburgh

1. Chief Veterinary Inspector to the City of Edinburg.
Because of the apparent frequency with which the meat worker becomes infected with one of the zoonoses, we decided to assess the incidence of $\mathrm{Q}$ fever, brucellosis, leptospirosis, and louping-ill in Edinburgh abattoir workers. No comprehensive study in abattoir workers appears to have been carried out in this country, and we thought that such a survey might provide information of value to the public health authorities and to practitioners. Evidence of previous infection with one of these diseases was sought by clinical assessment and serological testing.

\section{Materials and Methods}

Blood was taken from 96 men employed at the Edinburgh abattoir: 45 were slaughtermen, including 8 pig slaughtermen, 35 were hide brokers, ${ }^{1} 13$ were gut cleaners, and 3 were employed as clerks.

\section{Clinical Methods}

The men were interviewed in detail, a standard questionary being used. They were questioned about their previous occupations, and in particular were asked whether they had ever been employed in any other occupation which may have predisposed them to infection with one of the zoonoses. The localities in which they had worked were recorded. They were questioned regarding contact with cows, sheep, pigs, and rats, and also whether they had ever drunk unpasteurized milk. A series of clinical questions was used to elicit possible symptoms of a

Hide broker-a man who sorts and grades hides. 
previous attack of $\mathrm{Q}$ fever, brucellosis, leptospirosis, or loupingill.

\section{Serological Methods}

$Q$ Fever.-There are two distinct phases of Coxiella burnetii - phase 1 and phase 2. After an infection with $C$. burnetii antibodies to the phase 2 antigen develop. In chronic infections and in cases of endocarditis antibodies to the phase 1 antigen can also be demonstrated. Complement-fixation tests were carried out according to the method of Bradstreet and Taylor (1962), using the phase 1 and phase 2 antigens of $C$. burnetii. The reagents were supplied by the Standards Laboratory for Serological Reagents, Central Public Health Laboratory, Colindale.

Brucellosis.-An initial screening test of each serum at a dilution of 1 .in 10 and 1 in 100 was performed with a standardized Brucella abortus concentrated agglutinating suspension prepared by the W.H.O. Brucellosis Centre at the Ministry of Agriculture, Fisheries and Food, Central Veterinary Laboratory, Weybridge, England. Positive results were confirmed on a quantitative basis by additional agglutination tests with the more sensitive abortus and melitensis suspensions prepared by the Standards Laboratory for Serological Reagents, Central Public Health Laboratory, Colindale.

Leptospirosis.-The sera were subjected to the microscopic agglutination tests, the antigens consisting of living suspensions of 10 different serotypes of pathogenic leptospires representative of the different serological groups into which the majority of types can be classified.

Louping-ill.-Haemagglutination inhibition tests (Clarke and Casals, 1958) were used to detect the presence of antibodies to the virus causing louping-ill.

\section{Results}

Of the 96 samples of blood tested a total of $46(47.9 \%)$ contained antibodies to one or more of the antigens employed. Six specimens $(6.2 \%)$ contained antibodies to more than one antigen; antibodies to C. burnetii, Br. abortus, and Leptospira canicola (one specimen), antibodies to $C$. burnetii and $B r$. abortus (one specimen), antibodies to $C$. burnetii and the louping-ill virus (three specimens), antibodies to $\mathrm{Br}$. abortus and $L$. canicola (one specimen).

$Q$ Fever.-Twenty-seven specimens of serum (28.1\%) contained antibodies to phase 2 antigen of $C$. burnetii. The range of titres to phase 2 antigen is shown in Table $I$. Two of these specimens also contained antibodies at a titre of $1 / 16$ to phase 1 antigen of $C$. burnetii. The positive results were distributed among the occupational groups as follows: slaughtermen 14 $(31.1 \%)$, hide brokers $9(25.7 \%)$, gut cleaners $2(15.4 \%)$, clerks $2(66.6 \%)$. Four of these men had previously worked on farms, while five had worked in abattoirs outside the Edinburgh area and may have acquired their infection from these sources. Four employees had at some stage consumed unpasteurized milk. A history suggestive of a previous infection of $Q$ fever was obtained from four of the men. None of the specimens from the eight pig slaughtermen contained antibodies to C. burnetii.

TABLE I.-Incidence of Antibodies to C. burnetii (Phase 2 Antigen)

\begin{tabular}{lll|l|c|c|c|c}
\hline $\begin{array}{l}\text { Titre to C. burnetii } \\
\text { No. of workers } . .\end{array}$ &.. &. & $1 / 16$ & $1 / 32$ & $1 / 64$ & $1 / 256$ & $\begin{array}{c}\text { Total } \\
27\end{array}$ \\
\hline
\end{tabular}

Brucellosis.-Antibodies to Br. abortus were detected in 12 specimens of serum $(12.5 \%)$. Table II shows the range and number of positive titres. These 12 specimens were obtained from five slaughtermen, four hide brokers, and three gut cleaners. In four instances there was a possible source of infection other than the abattoir. One man had worked on a farm, two had worked with animals overseas, and one had consumed unpasteurized milk. None of the men with positive serology could recall symptoms which might be attributed to a previous attack of brucellosis.

\begin{tabular}{|c|c|c|c|c|c|}
\hline $\begin{array}{l}\text { Titre to } B r \text {. abontus } \\
\text { No. of workers }\end{array}$ & $\frac{1 / 16-1 / 64}{9}$ & $\frac{1 / 100}{1}$ & $1 / 500$ & $1 / 1,000$ & $\underset{12}{\text { Total }}$ \\
\hline
\end{tabular}

Leptospirosis.-Six employees (6.2\%) showed serological evidence of a previous leptospirosis due to the serotype canicola (Table III). No other serotype was agglutinated. Four of the positive sera were from men who were employed as pig slaughtermen, and another was from a man who had previously worked in a piggery in Edinburgh. Half of the men specifically engaged in slaughtering pigs had antibodies to L. canicola. Two of the men with positive serology were known to have suffered from canicola fever in 1950 and 1957, and had titres of $1 / 30$ and $1 / 100$ respectively. One man had previously suffered from an unexplained fever. None of the sera from the hide brokers, gut cleaners, or clerical staff was positive.

TABLE III.-Incidence of Antibodies to L. canicola

\begin{tabular}{lll|l|c|c|c}
\hline $\begin{array}{l}\text { Titre to } L \text {. canicola } \\
\text { No. of workers }\end{array}$ & $\ldots$ & $\ldots$ & $1 / 10$ & $\underset{1}{1 / 30}$ & $1 / 100$ & $\begin{array}{c}\text { Total } \\
6\end{array}$ \\
\hline
\end{tabular}

Louping-ill.-Eight employees (8.3\%) were shown to have haemagglutination inhibition antibodies to the louping-ill virus (Table IV). The positive results were distributed among the different occupational groups-slaughtermen (1), hide brokers (4), gut cleaners (2), clerks (1). One of these men had worked on a farm in Ayrshire in 1924, but the remainder had not been employed in other occupations or localities which might have predisposed them to infection. One employee gave a history of meningitis, but review of his hospital records showed this to be a meningococcal meningitis.

TABLE IV.-Incidence of Antibodies to Louping-ill Virus

\begin{tabular}{ll|l|c|c|c|c}
$\begin{array}{l}\text { Haemagglutination inhibition titre . . } \\
\text { No. of workers }\end{array}$ & $1 / 10$ & $1 / 40$ & $1 / 80$ & Total \\
8 &.. &.. & 1 & 5 & 2 & 8 \\
\hline
\end{tabular}

\section{Q Fever}

\section{Discussion}

Most authorities would agree that the presence of antibodies to $C$. burnetii indicates a previous infection with this agent. The incidence of antibodies in blood donors in Great Britain is about $4 \%$ (Evans, 1956 ; Marmion et al., 1956). As a basis for comparison all sera examined at the City Hospital, Edinburgh, during 1960-4 have been reviewed. In this period a total of 606 sera from patients admitted to or referred to the City Hospital, Edinburgh, were tested for antibodies to C. burnetii (phase 2 antigen). Most of these patients were suffering from a respiratory infection or from a pyrexia of unknown origin. The overall incidence of phase 2 antibodies (titre $1 / 16$ or greater) in the hospital patients was $3.5 \%$, compared with an incidence of $28.1 \%$ in the Edinburgh abattoir workers. If a titre of $1 / 64$ or greater is considered, the incidence in the hospital patients is $0.5 \%$, compared with $12.5 \%$ in the abattoir workers. These figures suggest that in Edinburgh the abattoir worker is particularly liable to acquire infection with $C$. burnetii, presumably by reason of his occupation. Infection is probably transmitted by contact with cattle and sheep despite the apparently low incidence of infection in these animals in Scotland. Slavin (1952) showed that $6.9 \%$ of herds of cattle in England were infected with $C$. burnetii but that 
only $0.8 \%$ of herds were infected in Scotland. Grist (1956) found only $0.7 \%$ of sheep infected in South-west Scotland. Pigs are an infrequent source of infection, which may explain the absence of antibodies to $C$. burnetii in pig slaughtermen.

The inability of the workers to recall symptoms which could be attributed to a previous attack of $Q$ fever is possibly explained by subclinical infections or because $Q$ fever may pass unrecognized and be regarded as an attack of influenza or bronchitis. The presence of complement-fixing antibody to phase 1 antigen in two employees may indicate past persistent infection (Powell and Stallman, 1962).

\section{Brucellosis}

From a national survey of brucellosis in 1960-1 it was estimated that $25-30 \%$ of the dairy herds in Britain are infected, involving $2.07 \%$ of the total cow population. On the basis of tests on individual cans of milk it was further estimated that $6.7 \%$ of can milk contains live brucella organisms (Leech et al., 1964). In addition the beef herds must constitute an important reservoir of infection.

It has been shown that about $1 \%$ of the general population have antibodics in their blood resulting either from drinking unpasteurized milk from infected herds or from contact with infected animals (Bartram et al., 1963). This has been confirmed recently by a survey of serum from blood donors in South-east Scotland (Coghlan, to be published). The agglutination test is not entirely specific for brucellosis, since brucellae, Pasteurella tularensis, and the cholera vibrio have antigens in common. However, an agglutination titre of 1 in 10 and above has for the purposes of this investigation and for that of the survey of blood donors been taken as evidence of past or present brucella infection. Antibodies to $\mathrm{Br}$. abortus at a titre of 1 in 10 and above were detected in 12 of the 96 abattoir workers $(12.5 \%)$. This is significantly greater than the incidence of $1 \%$ detected in the general population.

The absence of a history suggestive of a previous attack of brucellosis may be because the symptoms of uncomplicated brucellosis are often non-specific.

\section{Leptospirosis}

It is unlikely that sera from persons who have not come into contact with leptospires will contain leptospiral antibodies. In this survey the detection of $6.2 \%$ of workers with antibodies to the canicola serotype is thought to be significant. Human infections result from contact with infected pig urine. It has been shown that in the Edinburgh area pigs are particularly liable to infection by this serotype (Coghlan et al., 1957; Coghlan and Norval, 1960). It is interesting that five of the six workers with positive serology gave a history of contact with pigs.

\section{Louping-ill}

Previous studies in Great Britain, though limited, have suggested that it is unusual to detect antibodies to louping-ill virus in the human population. This is so even in samples from patients in whom there was a recorded history of illness resembling acute poliomyelitis (Likar and Dane, 1958) or meningo-encephalitis (Ross and Gourlay, 1961). According to Williams and Thorburn (1962) only one of 150 human serum specimens from a rural population, including a group in direct occupational contact with sheep, showed evidence of infection.

We have found an incidence of louping-ill infection of $8.3 \%$ in worl....s in the Edinburgh abattoir, which is in keeping with the fandings of Lawson et al. (1949) in the Glasgow abattoir. The abattoir workers stated that occasionally they encountered ticks in the course of their work. Contact with the blood of sheep might increase the risk of infection through skin abrasions, but in both the Glasgow and the Edinburgh abattoirs there was a higher incidence of infection in hide brokers. It is not possible to say whether infection arose through contact with ticks or with animals entering the slaughterhouse with a viraemia due to louping-ill.

\section{Summary}

Evidence of previous infection with $Q$ fever, brucellosis, leptospirosis, and louping-ill was looked for in 96 men employed at the Edinburgh abattoir. The men were asked relevant questions, and a specimen of blood from each was tested for serological evidence of those diseases; 46 (47.9\%) showed serological evidence of previous infection. The incidence of antibodies to Coxiella burnetii (phase 2) was $28.1 \%$, to Brucella abortus $12.5 \%$, to Leptospira canicola $6.2 \%$, and to the virus causing louping-ill $8.3 \%$. With the exception of leptospirosis it was not possible to obtain historical evidence of previous infection with these diseases. This may be because the symptoms pass unrecognized or possibly because the majority of infections are subclinical. It is assumed that the men mainly acquire infection by reason of their occupation.

We wish to thank the abattoir employees who participated in this study, and also the managerial staff for their cooperation. We are indebted to Mrs. Jean Smith for technical help with the brucellaand leptospira-agglutination tests. We are most grateful to Professor John Crofton, Professor Robert Cruickshank, Dr. J. L. Gilloran, and Dr. R. H. A. Swain for their advice. It is a pleasure to acknowledge the continued encouragement of Dr. A. C. Douglas.

This study was supported by the Wellcome Trust and the Scottish Hospitals Endowment Research Trust.

\section{REFERENCES}

Alston, J. M., and Broom, J. C. (1958). Leptospirosis in Man and Animals. Livingstone, Edinburgh.

Bartram, H. G., Bothwell, P. W., Jebb, W. H. H., McDiarmid, A., and Preston, A. E. (1963). Brit.' F. prev. soc. Med., 17, 95.

Beech, M. D., Duxbury, A. E., and Warner, P. (1962). 'f. Hyg. (Lond.), 60,1

Bothwell, P. W. (1963). Practitioner, 191, 577.

Bradstreet, C. M. Patricia, and Taylor, C. E. D. (1962). Mth. Bull. Minist. Hlth Lab. Serv., 21, 96.

Clarke, D. H., and Casals, J. (1958). Amer. F. trop. Med. Hyg., 7, 561. Coghlan, J. D., and Norval, J. (1960). Brit. med. f., 2, 1711.

- and Seiler, H. E. (1957). Ibid., 1, 257.

Dalrymple-Champneys, W. (1960). Brucella Infection and Undulant Fever in Man. Oxford Univ. Press, London.

Derrick, E. H. (1937). Med. F. Aust., 2, 281.

Evans, A. D. (1956). Mth. Bull. Minist. Hlth Lab. Serv., 15, 215.

Forbes, B. R. V., and Wannan, J. S. (1964). Med. F. Aust., 1, 262.

Grist, N. R. (1956). Scot. med. F., 1, 173.

Irons, J. V., and Hooper, J. M. (1947). F. Amer. med. Ass., 133, 815.

Lawson, J. H., Manderson, W. G., and Hurst, E. W. (1949). Lancet, 2, 696.

Leech, F. B., Vessey, M. P., Macrae, W. D., Lawson, J. R., MacKinnon, Derd, Ministry of Agriculture, Fisheries and Food, Animal Diseases Herd, Ministry of Agriculture, Fisheries and
Surveys, Report No. 4. H.M.S.O., London.

Surveys, Report No. 4. H.M.S.O., London.
Likar, M., and Dane, D. S. (1958). Lancet, 1, 456.

Likar, M., and Dane, D. S. (1958). Lancet, 1, 456. R. G. (1956). F. Hyg. (Lond.), 54, 118.

Powell, O. W., and Stallman, N. D. (1962). Ibid., 60, 359.

Ross, Constance A. C., and Gourlay, C. H. (1961). Lancet, 2, 527.

Shepard, C. C. (1947). Amer. F. Hyg., 46, 185.

Tonge, J. I., and Kennedy, J. M. (1963). Med. ₹. Aust., 1, 340.

Williams, H., and Thorburn, H. (1962). Scot. med. f., 7, 353. 